\title{
Learning From Exploring S-STEP Literature: Making Meaning From a Systematic Review of Discipline-Focused Self-Studies
}

\author{
Christi U. Edge \\ Northern Michigan University
}

\begin{abstract}
Drawing from a metasynthesis (Edge \& Olan, 2020), in order to explore the question, "What meanings did I make from conducting a systematic review of discipline-focused self-study literature?" this inquiry sought to better understand how content-area knowledge and practice is situated within multiple, interconnected systems shaped by power and privilege. Results include understanding and positioning literature as "critical friends," extending a theoretical framework from the content areas to self-study research design and practice, and questioning privilege and power in exploration. Implications address how self-study of teacher education practices methodology can position higher education faculty for contributing to equity and justice.
\end{abstract}

Keywords: self-study of teacher education practices, content area, meaning-making, transactional theory, teaching practices, educational responsibility, critical friend, discipline, experience, higher education faculty, systematic review, qualitative metasynthesis

\section{CONTEXT}

At the 2016 Self-Study of Teacher Education Practices (S-STEP) Castle Conference, I chose to participate in round-table style conversations intended to uncover needed foci for a second edition to the International Handbook of Self-Study of Teaching and Teacher Education Practices (2004). Although the conversation took place after dinner, late into the evening after many intense days of conference events, I found the energy generated amidst circles of researchers to be electrifying and exciting. In the first round of discussions, I remember sitting in the circle, listening and feeling ideas bubble up and connect to what others were saying, sparking "What-if...?" and "How-about...?" ideas. Putting on my teacher hat, I imagine Mandi Berry, who was leading this first conversation, must have observed my half-breath, unsuccessful starts into the conversation, for amidst the flow of talk from much more seasoned self-study researchers, she interrupted the back-and-forth of the conversation to invite me to share (presumably, what I was thinking in that moment). I doubt I said anything profound, but the experience was something, a small start, an externalization of internal thought, a step into what would become a journey. In the second round of conversations, I joined a group exploring the topic of self-study of practice in the content-area disciplines. In these seemingly simple events, I transformed internal thought into speech beyond myself, speech into conversation that later launched discourse with a critical friend through investigating a body of research.

Several months after these Castle Conference conversations, a section editor invited me to contribute to the handbook by addressing literacy/language arts education. In January of 2017, I submitted an outline for the chapter, and in September, I invited a language arts teacher educator and S-STEP researcher to "join 
me in the scholarly adventure" (personal communication, 9-23-17). Together, we read and analyzed a data set of 77 S-STEP publications. In order to speak to Vanassche and Kelchtermans's (2015) and Zeichner's (2007) calls for accumulating knowledge across self-studies, "especially within specific content areas" knowledge that is committed to a "practice-based, yet theory-building research agenda" (Vanassche \& Kelchtermans, 2015, p. 523), we sought to illuminate findings from the existing knowledge base through a review of literacy, English language arts, and reading education self-study research. As readers of the literature then later as writers of the handbook chapter, we individually and collaboratively made meaning that led to new understandings - some of these meanings are publically represented in our (Edge \& Olan, 2020) published chapter, while others live on in us, represented and enacted in our practices.

\section{PURPOSE}

This paper draws from a larger, systematic study (Edge \& Olan, 2020), in order to begin to explore the following question: "What meanings did I make from conducting a systematic review of discipline-focused self-study literature?" This inquiry aims to contribute to the broader call to educational researchers to accept educational responsibility and to the S-STEP call, specifically, by seeking to better understand how contentarea knowledge and practice is situated "within multiple, interconnected systems...shaped by power and privilege" in order to "consider the ways we may be disrupting and/or reproducing oppressive systems and structures in institutions of higher education..." (Martin \& Mills, 2020). As Crowe (2020) has argued, exploring discipline-focused self-study is a way to cross boundaries, engage with diverse perspectives and knowledge, and continue to expand S-STEP research. Results from this inquiry include learning through transacting with the literature as a critical friend. This nuanced finding is presented in relation to the finding of learning through extending a discipline-focused theory to self-study research design and practice. Implications, I think, interrupt the flow of S-STEP research, for, perhaps just a moment, to invite other bodies of knowledge into existing scholarly conversations. In light of future journeys beginning to be envisioned (and yet to be imagined), the present paper may be an initial, half-breath effort to enter new conversational spaces, inviting others to attend to the potential for how disciplinary literacy and self-study are transformative tools are capable of making more visible how, by whom, and for what purposes knowledge is constructed, represented, and enacted.

\section{PERSPECTIVES/THEORETICAL FRAMEWORK}

This inquiry is situated in a transactional paradigm, adopting the epistemological stance that humans are active meaning makers who share an ecological relationship with their environment (Connell, 2008; Dewey, 1938; Dewey \& Bentley, 1949; Edge, forthcoming; Rosenblatt, 1978, 1994, 2005). Informed by the Transactional Theory of Reading (Rosenblatt, 1978/1994; Rosenblatt, 2005), a narrative view of experience (Clandinin \& Connelly, 2000), and feminist communication theory (e.g., Belenky, Clinchy, Goldberger, \& Tarule, 1986; Belenky, Bond, \& Weinstock, 1997; Colflesh, 1996), educational researchers, teacher educators, and other professional practitioners are positioned as active meaning makers who can read and make meaning from lived experiences.

The Transactional Theory is most commonly associated with Rosenblatt's Transactional Theory of Reading and Writing (1978/1994) and with Reader Response Theory, which is the Transactional Theory applied to literary criticism and to the teaching of literature (Probst, 1987). The essence of this theory is that "[e]very reading act is an event, or a transaction involving a particular reader and a particular pattern of signs, a text, and occurring at a particular time in a particular context" (Rosenblatt, 2005, p. 7). The reader and the text are not fixed entities acting upon one another like parts of a machine or colliding billiard balls, explained Rosenblatt; the reader and the text are "two aspects of a total dynamic situation" (2005, p. 7).

Rosenblatt's Transactional Theory holds particular implications for meaning-making. Rosenblatt wrote, "Meaning - whether scientific or aesthetic, whether a poem or a scientific report - happens during the interplay between particular signs and a particular reader at a particular time and place" (Rosenblatt, 
2005, p. x). Meaning is not an object or even an idea; it is a doing, a making, an event in time (Polkinghorne, 1988; Rosenblatt, 1969, 1978, 1985, 1994, 2005; Unrau, Alvermann, \& Ruddell, 2013). This inquiry sought to identify events and to critically consider meanings I made from conducting a systematic review of SSTEP literature as a way to address the American Educational Research Association (AERA) call to accept educational responsibility (Harper et al., 2021).

\section{METHODS}

The broader study from which this paper draws was a systematic review of existing S-STEP literature that replicated Vanassche and Kelchtermans's (2015) systematic review of self-study research published 1990-2012. Our review (Edge \& Olan, 2020) focused on recent (2006-2017) S-STEP literature related to the specific content areas of reading, literacy, and English language arts education. The larger, metasynthesis study addressed self-study researchers' discipline-focused meaning-making and our own collaborative meaning-making about how S-STEP might advance or challenge our disciplinary field. In the year between completing the manuscript and its publication, I began to look again at the reading-writingresearch represented in the manuscript, my journal, and our running notes as critical friends and co-authors. I sought to more fully identify and question the understandings and knowledge I generated through exploring S-STEP literature with a critical friend: "What meaning(s) did/do I make from conducting a systematic review of discipline-focused self-study literature?" and "How do these help me to understand and accept the AERA call for "accepting educational responsibility"?

\section{Data Sources}

The systematic review included publications from three groupings of literature that fit a priori criteria-namely, LaBoskey's (2004) descriptors for self-study research: initiated by and focused on the self; improvement aimed; interactive; utilizes multiple, mostly qualitative methods; and defines validity in terms of trustworthiness. The first grouping included discipline-focused articles, book chapters, and monographs published within the S-STEP community (2005-2017). The second included articles in journals outside of the self-study discourse community. The third drew from S-STEP Castle Conference proceedings (20062016). In total, our final set included 77 peer-reviewed publications.

\section{Data Analysis}

We replicated the in-case and cross-case data analysis approach Vanassche and Kelchtermans (2015) utilized for their systematic review of self-study literature (Edge \& Olan, 2020). Our review differed in that (1) we focused on disciplinary self-studies related to literacy, reading, and English language arts education, and (2) we employed a theoretically-informed analytical reading--that is to say, we analyzed data through systematic interpretive reading that was guided by the Transactional Theory (Rosenblatt, 1978; 1994) as a specific disciplinary-focused frame--to address our research questions.

Within-case analysis (Miles \& Huberman, 1994) included examining each publication as a unit of analysis, independently reading and charting extensive notes and wonderings (e.g., Is meaning-making implied or stated in data analysis? To what extent do the researchers provide examples of making meaning?) We met weekly via Skype to discuss memos, observations, and thinking about what we were reading. We also kept notes as critical friends to track our conversations and meaning-making. Through discussion, we engaged in constant comparative analysis (Strauss \& Corbin, 1998), coding data for emerging themes, patterns, and outliers.

Cross-case analysis (Miles \& Huberman, 1994) included identifying themes across publications. The "recursive nature of the data collection-analysis-interpretation process" inspired new questions, additional reading, and emerging insights over time (Pinnegar \& Hamilton, 2009, p. 149). We then produced a themes chart with examples across studies.

During the writing of the manuscript, we refined our responses to the inquiry questions, employing writing as data analysis (Richardson \& St. Pierre, 2005); we continued to engage in discourse and 
collaborative meaning-making, checking our interpretations against the texts, re-reading as necessary, and parsing out themes in relationship to the emerging whole of the study and the chapter.

Throughout the study, I wrote journal notes and kept dated drafts of the manuscript, noting in comments or on the manuscript my thoughts and revisions to my thinking as a result of reading and writing during the writing as data analysis phases of the study. Though not intended, I significantly refined and developed the theoretical framework for the manuscript in response to the findings and inquiry questions. Recognizing this as I finalized the manuscript was a critical event that initiated my present focus for identifying and critically considering my meaning-making from the metasynthesis of extant, disciplinary self-study literature. Multiple drafts, journal entries, handwritten notes and coding notes on data, and discourse with my critical friend as co-author (Olan \& Edge, 2019) helped to facilitate and document my meaning-making.

Although I consider this article a draft of thought, articulated for purposes of continued inquiry (Richardson, 2000; Richardson \& St. Pierre, 2005), a way of continued knowing through writing (Kitchen, 2020), conversation with others for purposes of continued envisionment-building (Langer, 2011a), I aim to address initial findings through trustworthiness situated in a relational ontology evidenced in vulnerability, depth of revelation, related to practice over time and across contexts, within the context of my lived experiences, and in relation to communities of practice (Hamilton et al., 2020).

\section{RESULTS}

The meaning-making experience represented in the published handbook chapter resulted in identifying, refining, extending, and challenging my existing beliefs and theoretical underpinnings in response to making meaning from disciplinary and disciplinary-focused S-STEP literature. Learning from the exploring the S-STEP literature, I found the literature like critical friends who could prompt and challenge me to extend and refine my understandings in ways that impact my enactment of self-study as well as my teaching practices by helping me to develop additional awareness and assumptions in my teaching and research practices.

\section{Learning From Exploring the Literature: Literature as a Critical Friend}

One meaning I made was that literature served as a critical friend during my inquiry into the literature. In addition to the critical friend who was also my co-author, transactions with mentor texts - texts I intentionally studied to examine how they were crafted for purposes of my own learning and with like texts - other S-STEP studies I attended to with the intent of learning about research and practice in relation to my inquiry question. These two types of external, printed, texts prompted the framing and reframing of my understanding as an internal text and my teaching and research practices as enacted, lived texts.

\section{Mentor Texts as Critical Friends}

In the early stages of this inquiry, as I was forming initial wonderings (Edge \& Olan, p. 787) that would later become the research questions (pp. 787-788) represented in the metasynthesis printed in the handbook, I discovered a recent disciplinary review of literature conducted by Purcell-Gates et al. (2017) in which the researchers utilized theory to frame their review. The authors explicitly identified the theoretical review as a departure from past handbook reviews and offered a rationale for their frame as well as a detailed explanation of their theoretical frame itself. This exemplar or mentor text evoked my memories and gave shape to what felt, at the time, like my "instinctive," disciplinary-rooted thinking. Their chapter inspired me to act on my idea of considering S-STEP literature from a disciplinary theoretical perspective. Although I expressed the idea of utilizing a theoretical perspective during the handbook discussion at the 2016 Castle Conference, I did not yet know what this work would actually entail or how this would happen. My idea took up prior knowledge and experiences from past meaning-making events and helped me to imagine a horizon of possibilities in which I could begin to imagine using existing knowledge in a new way. Seeing that and studying how other respected disciplinary scholars had framed a review of literature from a disciplinary theoretical perspective served as a mentor text. Thorough reading and transacting with this 
mentor text many times during the two years of inquiry that resulted in the handbook metasynthesis, I came to understand how, in the context of S-STEP research, a mentor text can be a critical friend.

Transactions with this self-selected mentor text evoked a kind of critical, metacognitive conversation; this interactive conversation served as a source of learning, an event through which I made meaning, and a scholarly scaffold for framing and reframing my own developing ideas and inchoate understandings. From Durkin's (2003) work, I understand and have observed over time in drafts of teaching materials I've produced, my research (Edge, 2011; Edge, forthcoming), and self-study of teaching practices (e.g., Edge \& Olan, in press) that readers construct an internal text in their mind, as they read and make sense of the external text they attend to. The internal text is developed before, during, and after a reading event, as a reader makes text-to-text, text-to-self, and text-to-world connections, and as a reader employs various comprehension strategies such as asking questions, re-reading, or making inferences (Keen \& Zimmerman, 2007; Tovani, 2004).

Examining Purcell-Gates et al.'s (2017) thorough review of extant disciplinary research in the form of the published chapter, I held my purpose for reading in mind, and I employed a stance of openness, of exploration, of seeking to understand and to refine my initial ideas by studying how they used theory, organized and presented their ideas, and extended understandings in the context of the field and in the context of my personal ongoing becoming (Pinnegar et al., 2020) as a teacher educator and S-STEP researcher. I attended to what the researcher-authors wrote, but also how they reasoned and communicated in relation to the theoretically framed review of the literature, in relation to the literature they discussed, and in relation to my own knowledge of research and practice in the disciplines of reading, literacy, and English language arts. Upon the printed version of Purcell-Gates et al.'s (2017) chapter, layers of my multicolored highlighting, text marking, marginal notes with brief connections, "ah-ha's," and new ideas are visible mementos, and served as a tool for holding my thinking to remember and reuse it (Tovani, 2004), to re-engage in my meaning-making at a later time, and to spark additional transactions between drafts of my understanding and the communicative signs from this critical friend. Transactions with this text framed my thinking and provided a platform for dialogic interactions between the external and internal texts in the intersecting contexts of S-STEP and disciplinary literature around an articulated, albeit still fluidly evolving purpose.

\section{Like Texts as Critical Friends}

My existing and developing understandings were also made more visible to me by my reading, responding to, and learning from the experiences, values, contexts, and knowledge articulated in self-studies by other teacher education researchers. Like texts are those that communicated and represented different contexts, problems of practice, literature, frameworks, or findings, yet communicated enough similar details for me to be able to connect my experiences to those of other authors, and in the space of those connections, imagine new horizons of possibilities or more intricately weave the text of my thinking. For example, Parsons (2016) explicitly framed her literature for adolescents course with two literacy/language arts literary theories and wrote that these two theories shaped her approach to teaching, responding to, and discussing literature. She also demonstrated that she read her students' written transactions to literature in order to make meaning about her teaching, through the lens of these same theories.

Parsons's (2016) article, published in a journal I don't typically read, was selected as part of our data set, as a self-study in the context of the discipline we were investigating. Our primary research question guided my thinking about her study in the frame of her meaning-making, and thus contributed to a public theme in the handbook chapter, Content-Area Knowledge as a Frame to Explore Teaching, Teacher Education, and Self-Study Methodology in Self-Study. Our secondary research question invited our meaning-making into the reading and data analysis event. Parson's study evoked my own ongoing theorizing and enactment of theory in my teaching practices. One particularly significant aspect of Parsons's study was that she referenced two theorists, Rosenblatt and Langer, whose theories had and continue to significantly shape and reshape my research and teaching practices. In the margins of the printed article are exclamations of excitement, and thoughts agreeing, extending, connecting, and my talking back to the arguments and theoretical framing of Parsons's work. Although it may be possible other S-STEP 
researchers have connected these two theorists' work, this was the first time I had read a text that combined what is often interpreted as competing and incongruent theories regarding stance and meaning. In my thinking and research (e.g., Edge 2011; Edge et al., in press; Edge, 2018; Edge, forthcoming) these two theories complement each other and offer distinctions and distillations relevant to knowledge, experience, teaching, reading, writing, and living when viewed narratively. Different critical friends as co-researchers had, no doubt ad nauseam, listened to me talk about these theories for years, through multiple studies, and over time. These theories are explicitly named and synthesized in frameworks for teaching and in content and applied strategies evident in my teaching practices for the last two decades. When I read Parsons's article - to state it in a colloquial phrase - I totally geeked out. I vividly remember sharing my excitement and curiosity with my critical friend and co-author for the handbook chapter.

Exploring and critically considering Parsons's (2016) research and teaching experiences heightened similarities and differences to my own enactment and co-constructed enactments of these theories in my teaching and in both my individual and collaborative research practices. Reading, comparing and contrasting, imagining, and wondering about others' self-studies served as a critical friend in that others' experiences and rich descriptions offered frames for thinking, reflecting, and imagining what else was possible and might be possible. Seeing how others used discipline-informed theory to study their teaching practices offered the opportunity to juxtapose my own experiences, objectify and refine them in response to S-STEP literature.

Prior to this present S-STEP inquiry, I had heard others informally and perhaps formally talk at S-STEP conferences about literature as a critical friend in response to others' presentations (e.g., Thomas, 2018). In those moments, I could nod in the agreement afforded by my existing knowledge and experiences at that time. These dormant thoughts were brought to light in a personal, relational way when I engaged in the experience of reviewing (reading and analyzing) disciplinary self-study literature. From the perspective of envisionment building, these experiences were ways of "being in and moving through an envisionment" (Langer, 2011, p. 22).

The act of synthesizing the literature around thematic findings for an imagined audience, provided a second, related, but distinct context for developing a critical friendship with the literature. Initially, my awareness and thinking about the critical friendship afforded by mentor and like texts was surface-level, backgrounded in my thinking. Yet, through recognizing my meaning-making from conducting the systematic review, I considered, from the more distanced vantage point of a now completed handbook chapter and framed by a new inquiry, I too discovered how literature could be positioned as a mentor and a like critical friend "whose" linguistic-experiential reservoir (Rosenblatt, 1978/1994) represented upon the printed pages and even the white space within the margins serves as a sounding board, plays an active role in constructing understanding, as well as frames and reframes thinking.

\section{Learning From Exploring the Literature: Extending Discipline-Focused Theory to Self-Study Research Design and Practice}

A second outcome of my meaning-making from engaging in a metasynthesis of the self-study literature includes developing theoretical ideas and applying them to new contexts. Applying an analysis of disciplinary-derived theories to my own actions and lived experiences, I can identify this outcome as representing a stance of learning Langer (2011) describes as "going beyond," when learners develop rich envisionments that they can apply or use in new and sometimes unrelated situations, enabling them to

...move from the one learning experience to another, from one richly developed envisionment to the beginnings of a new one. To do this, we select critical concepts from the present envisionment and enter into a new envisionment-building experience, making connections and drawing on our previous knowledge. (p. 23).

From the frame of envisionment-building stances, I can see in the chapter drafts, planning documents, and email conversations with the section editor that my deeply constructed understandings about the Transactional Theory were consciously and purposefully applied to this new situation of conducting a 
metasynthesis. I can also see that beginning a new envisionment-building experience was a way of entering into metaphorical conversations with S-STEP researchers/authors, prompting me to re-see connections, and to broaden and deepen knowledge in the new events framed by the literature.

For example, Purcell-Gates and colleagues (2017) articulated teaching and learning could be seen as one process; an idea I too had long held, first as tacit knowledge then studied during several doctoral studies projects, enacted in my dissertation research (Edge, 2011) and extended through collaborations and conversations with various groups of critical friends (Bergh et al., 2018; Cameron-Standerford et al., 2016; Edge \& Olan, 2021; Edge, forthcoming; Edge et al, in press; Olan \& Edge, 2019). Returning to these ideas in light of the disciplinary-focused review of literature and the S-STEP literature enabled me to refine and develop thinking, challenge assumptions, and explore ideas through others' frames of reference, inquiry questions, contexts, and in light of their findings. Identifying a few connected events, I can more clearly see how, in the context of writing the handbook chapter, I extended into words, ideas that I previously understood, tacitly.

In 2011, I wrote about how reading and responding to one's lived experience through disciplinaryinformed theoretical framework could enable one to position that experience like a text. In a 2016 AERA paper, two critical friends and I first shared a broadened definition of text to take up lived experiences (Edge et al., 2016) in the context of S-STEP research and practice. Encouraged by feedback at AERA, we then wrote and shared this understanding of experiences as texts with conference delegates at the S-STEP International Biennial Conference ("Castle Conference"):

We defined text in a broader sense to include the idea that lived experiences once textualized (Edge, 2011) could then be shared, interpreted, reinterpreted, and analyzed. Textualizing our lived experiences and studying them through collaborative self-study methodology, we have learned how to construct meaningful understating about our teaching practices. We have learned how to empower others-prospective teachers, practicing teachers, administrators, and colleagues to intentionally study their own lived experiences like texts. (Cameron-Standerford et al., p. 371)

However, meaning-making from teaching for purposes of improving teaching, alone, is not enough for accepting educational responsibility as educational researchers (Edge \& Olan, 2020). For us to contribute to S-STEP by broadening and deepening understanding of the complex teaching-learning process (LaBoskey, 2004), we should make more visible the processes for meaning-making. One strategy for working toward this purpose is through textualizing lived experiences.

Textualizing experiences goes beyond reflection; it objectifies a lived experience in a way that permits both an individual and others to first see the experience outside of themselves and then to re-enter the reading of that experience as a new event through which one makes meaning. (Cameron-Standerford et al, 2016 as cited in Edge \& Olan, 2020, p 808)

Through multiple iterations of reading and writing over time, I began to notice how other researchers built upon, refined, and extended their own and others' ideas over time as well. For example, building on existing research (Barr, 2001; Hall, 2006; Rosenblatt, 1985a), Purcell-Gates, Duke, and Stouffer's (2017) review of research on teaching literacy and learning to read draws upon Rosenblatt's Transactional Theory to extend the ecological relationship between a reader and text in a particular context during a reading event to teaching and learning in the learning to read event. They "use the term transaction to indicate that teaching and learning are viewed as one process and not an interaction of two separate entities" (Purcell-Gates, Duke, $\&$ Stouffer, 2017, p. 1220). Purcell-Gates and colleagues expand the definition of " "teaching reading' to one of "teaching/learning to read" "and they intend "the two terms to be interchangeable" (p. 1220). Agreeing with Purcell-Gates and colleagues that teaching and learning are transactional; they are one process not merely an interaction of two separate entities, I wrote, "Teaching and learning share an ecological relationship..." (Edge \& Olan, 2020). 
Rereading their tightly synthesized words after reviewing research and my own initial articulation of our theoretical frame, I began to further develop my understanding of how reading and writing; teaching and learning; teacher education practices and learning to teach share ecological, transactional relationships when viewed through the transactional paradigm (Dewey \& Bentley, 1949) and through considering the Transactional Theory of Reading and Writing (Rosenblatt, 1978/1994) through implications for research (Rosenblatt, 1985), professional learning (Edge, 2018) and teaching practices (e.g., Bergh et al., 2018; Bergh et al., 2020; Edge, 2011; Edge, forthcoming; Edge, 2019; Edge et al., 2020).

Framing our review of existing self-study literature in the content areas of reading, literacy, and English language arts with the theoretical perspective that reading, writing, teaching, and learning are transactional processes, I extended and expanded the definitions of "reader," "text," and "context" to the situation of selfstudy of teacher education practices. Said another way, I found the epistemological tenets of Rosenblatt's Transactional Theory to connect with and extend to self-study methodology. In self-study, one's self (one's thoughts, actions, ideas, personal history, existing knowledge), contexts, and one's professional practices, can be objects of study; they can be seen as texts self-study researchers compose, read, and make new meanings from investigating.

In the final drafts of preparing the manuscript for the handbook, I realized there was much I had thought or assumed but not stated about the way that I envisioned the transactional theory applying to the context of teaching and to studying teaching and teacher education practices through self-study methodology. It was from the more objectified stance of considering how others might read the chapter, reading over a PDF formatted copy of the chapter from a "reading" rather than "writing" mode of thought in a Word document that I frequently distanced myself, asking questions that as a reader, I might wonder. I would read, realize more was needed, and step back into the Word document to continue writing. This (tortuous but productive) process resulted in significantly expanding the theoretical framework section for the handbook chapter. As I wrote, I defined the core tenets of Rosenblatt's Transactional Theory in the context of studying teaching practices, and I added a section explicitly labeled "Extending the Transactional Theory to Self-Study of Teaching Practices” (pp. 784-785).

Framing our review of existing self-study literature in the content areas of reading, literacy, and English language arts with the theoretical perspective that reading, writing, teaching, and learning are transactive processes, we consciously extend the definitions of "reader," "text," and "context" to the situation of self-study of teacher education practices. Said another way, we found the epistemological tenets of Rosenblatt's Transactional Theory to connect with and extend to self-study methodology. In self-study, one's self (one's thoughts, actions, ideas, personal history, existing knowledge), contexts, and one's professional practices, can be objects of study; they are texts self-study researchers compose, read, and make new meanings from investigating. One purpose of S-STEP research is to articulate and to refine one's professional expertise and understanding of teacher education practices (Vanassche \& Kelchtermans, 2015). Another purpose is to produce knowledge that can inform "the complex and ever-changing process of teaching" (Gatlin et al., 2002, p. 13) to generate understandings that can be shared with others (LaBoskey, 2004). Contexts are varied but clearly articulated in existing literature. "The knowledge developed in and through self-study cannot be disconnected from the complex reality it refers to, and is embedded in" (Vanassche \& Kelchtermans, 2015, pp. 515-516). The rich contexts in which knowledge of teaching and teacher education are evoked or discovered through self-study research have potential to inform, in context-sensitive ways, the broader, multifaceted knowledge bases of teacher education and reading, literacy, and English language arts education.

Writing, or really, revising this part of the theoretical framework for the manuscript also necessitated that I explain a connection of ideas. In the chapter, I saw this as an epistemological connection at the time: 
Epistemologically, we view individuals- that is, teachers, students, teacher educators, and researchers- as active meaning makers (Edge, 2011). As active, agentive meaning-makers, individuals use their existing knowledge, their linguistic-experiential reservoir (Rosenblatt, 1978/1994; 2005), to attend to cues in communicative signs or texts. Using a combination of senses and framed by particular purpose(s), readers make sense, that is, they read or negotiate the text to make meaning (Draper \& Siebert, 2010; Rosenblatt, 1978/1994; 2005). Readers make sense of external, multimodal texts which may include, for example, classroom situations, learners, curriculum, and alphabetic print texts; readers also compose and make sense of their internal texts including their own ongoing conceptual understandings and sense of identity. Each reading event is situated in particular contexts, which include professional practice settings, K-12 classroom teaching and learning settings, as well as the broader social and cultural contexts outside of "school," of which they are a part. One's linguistic-experiential reservoir is colored by social and cultural contexts and also contributes to those contexts, like a text ever being revised and (re)composed, as asserted by Geertz (1973/2008) who described society is an ambiguous cultural text that individuals read and compose. New understandings may broaden one's existing knowledge, and they may deepen or burrow that knowledge (Langer, 2011). For individuals whose existing knowledge is "on the verge," new, revised, or transformed understandings may create a sense of "wobble" (Fecho, 2011) as they work to recompose what they know and/or how they know.

Building from earlier independent and collaborative S-STEP research (e.g., Bergh et al., 2018; CameronStanderford et al., 2016; Edge, 2011; Edge, forthcoming; Edge et al., 2014; Edge et al., 2016), I consciously stepped into the experience of the metasynthesis adopting a stance toward our review of the literature guided by the Transactional Theory. As my critical friend and co-author (Olan \& Edge, 2019) and I proceeded to explore, read, and analyze the S-STEP literature, I gained additional insights into the connections between self-study methodology and theoretical underpinnings. One result is represented in broadening and applying the tenets of the Transactional Theory to teaching and S-STEP in the theoretical framework for the handbook chapter. Another is listing our new meanings we collaboratively made as insights (Edge \& Olan, 2020, pp. 811-812). Admittedly, there is much more to unpack.

\section{SIGNIFICANCE}

The purpose of this inquiry was to begin to explore the following question: "What meanings did I make from conducting a systematic review of discipline-focused self-study literature?" How to think about meanings, how, and where they are made are questions of "fundamental concern to literacy, schooling, social justice, and political process at all levels" (Burnett \& Merchant, 2021, p. 355). This inquiry aimed to contribute to the 2021 AERA call for "accepting educational responsibility" and to the S-STEP call by seeking to better understand how content-area knowledge and practice is situated "within multiple, interconnected systems...shaped by power and privilege" in order to "consider the ways we may be disrupting and/or reproducing oppressive systems and structures in institutions of higher education..." (Martin \& Mills, 2020) by exploring my own experiences navigating and negotiating. From the example outcome of extending a disciplinary theory from the context of teaching literature to studying teaching practices, I aim to (begin to) explore and articulate potential significances including: taking up the idea of an ecological relationship between disciplines and self-study of teaching practices in our meaning-making as teacher educators and self-study researchers and through seeing literature as a critical friend.

Through a disciplinary-focused lens, the transformative, agentive power, potential, and responsibility of self-study research to inform multiple facets of our work becomes ever-visible — or, at least increasingly

more visible. At the center of the concentric contexts of literacy, English language arts and reading, teaching and teacher education, and self-study of teaching practices, disciplinary literacy resides as a transformative tool. Moje, Dillon, and O’Brien (2000) write: 
Because literacy practices are shaped by discourses, literacy can be considered a powerful tool that can be used to claim a space or establish an identity or voice in various social interactions. The ways one uses literacy can have a profound impact on whether a particular literacy event, and its concomitant practice, is valued (p. 166).

The above paragraph is one that I found myself focusing on at the outset of the formal metasynthesis study; again when drafting ideas; when finalizing the chapter; when presenting an overview of the chapter for the handbook webinar; when writing this paper. From my experiences teaching and reading literature, and from studying disciplinary professional literature and the ideas of scholars over time (here that of Beers and Probst), I recognize the significance of an author repeating something "again and again" as a signpost to notice and note (Beers \& Probst, 2012). If I can recognize this significance in the writings of other authors, I must be willing (although it is a kind of tension to enact) to see my own "again and again" as a signpost to notice and note - an event I should consider critically, wonder into, and consider in the context of the larger whole as potentially meaningful.

While the idea that literacy is a transformative tool is not new in the disciplines of reading, literacy, and English language arts, or even in the broader context of education, there is space here to build upon existing knowledge to explore, build out, and define teacher education literacy practices through S-STEP methodology. If one sees teacher education as a discipline (e.g., Russell, 2004), then it becomes critical to consider how our discourses inform us and others, how it invites, or does not invite into the discipline of teaching, how we help teacher candidates or doctoral students to our language positions through articulating to self and others what our literacy entails, how we utilize literacy practices in our shared teacher education discipline and how disciplinary knowledge and theory might lend additional insights and entry points into teaching. Hold parallel for a moment, the finding (Levine, 2014) that learners in a 12th-grade class reported as being from a high-poverty, low-achieving, urban high school made gains that a comparative class did not, when those learners were taught to use everyday affect-based practices as interpretive heuristics; said another way, learners who were taught to recognize and ascribe valance to language they, as readers, felt was affect-laden, and then explaining or justifying those ascriptions, made gains in their ability to engage in literary interpretation. Said another way, making interpretation visible and creating space for the interpretive process by using what was accessible and everyday as a heuristic, novice readers learned to think and do like expert readers of literature.

Implications potentially challenge teacher educators to consider the relationship of disciplinary knowledge, values, and literacy practices and not only in disciplines, but also for teacher education as a discipline--for more socially just representations and enactments of knowledge through self-study of practice. Literacy and self-study are each transformative tools; together, they may be ecologically capable of making more visible how, by whom, and for what purposes teacher education knowledge is constructed, represented, and enacted. If literacy is thought of as discipline-informed ways of navigating, negotiating, and creating (Draper et al., 2010), how might S-STEP make more visible to themselves, to teachers, and to teacher candidates the largely invisible, transactional process of composing internal texts while attending to and reading the external observable texts of teaching or teacher education? How do we read teaching events and compose identity? How do we read learners and compose curriculum? How do we read being and compose becoming? These present questions are, admittedly conversations that feel difficulty to enter into. Nevertheless, as S-STEP researchers, we are immersed in them, living them, enacting them.

One of the affordances of S-STEP is that the aim of improving one's practice is largely practical and useful. As teachers, teacher educators, and teacher education researchers, we produce knowledge, insights, practices that we can and do use. Nevertheless, a potential limitation is that the processes through which we generate these practical usefulness-es can get lost, ignored, or refined away from our collective record and from our collective consciousness. Like a draft of a paper or a draft of a lesson we teach, what we say and write becomes more refined, focused, purposeful, and "clean"; the marginal notes in drafts of prior thoughts become irrelevant in the present draft — to the person who is drafting the thinking, although those thoughts helped make, work toward, and arrive at the next draft. Why might this matter? While I value the product, the efficiency and focus of the finer product, I must challenge myself (and by extension, us) to 
remember and to make - at least occasionally - the processes visible, to open up, for access to self and others, how, and why we make the meanings we call teaching, learning, and researching in our everyday practices. In the larger narrative of our collective practices, we are the messy, marginal notes. We are they who ask, connect, mark, respond, react, infer, and pen new thoughts. We are they who make - and who can and do teach others to make the meanings we call curriculum, teacher, leader, poem, event, chapter, handbook. Meaning-making events are happening all around us, even right now-they happen in classrooms, in teachers, in learners sitting in desks, on playgrounds, on busses, walking alone down the street. And, while not every meaning-making event is perhaps "profound" or "novel," to recognize the interconnected webs of meaning is to embrace that what we give space to, attention to, frame as possible can lead to changes and insights and transformation and new knowledge that otherwise would not have come into being in the life of that individual or our shared knowledge. To recognize that the next "Emily Dickenson" might be sitting in the desk right in front of you, listening, yet looking out the window, wondering, observing, composing and penning thoughts on scraps of paper is to accept some responsibility, to encourage, to include, to be quiet for a moment, to hold back the more refined thinking and give space to half-breath thoughts emerging in the moment, to trust and to imagine and to hope in that which is not yet but could be. To recognize that any of us is equally, profoundly, humbly, capable of making meanings is to accept responsibility to ask, to speak, to risk, to silence the inner critic and fear, to step into the moment, to be, to write, to form presently insignificant-yet-possible-future-somethings -- possibilities in the spaces between and alongside the margins. This is burdensome thought, because it reminds us that what we do and say (and don't) matters, affects us and others. To recognize and to embrace this weighty - even if "everyday"-- responsibility is to acknowledge the need for and the responsibility in framing process and product; theory and practice; reading and writing; self and other; living in and dying to self; affordances and constraints; speaking up and piping down; learning from and producing the literature.

\section{Why? and so What?}

I now see "it" a little more, everywhere around me-in the title of this paper even - that which was hidden in plain sight, what and why I've been engaged in this work. Learning, knowing, and meaningmaking are relational and ecological similar yet different and perhaps dependent upon each other.

- Meaning-making is to highlight the person, the researcher, teacher, student, whoever is doing the acting, they who have agency.

- Learning is to highlight the process, the actions that make use of strategies, resources, environments, texts, contexts.

- Knowing is to highlight an outcome that is never stable, always in process, always moving (or not), the meaning that is made.

- The meaning a learner has made is the result of their present and residue of their past meaningmaking. Their knowledge in their present time and space of their narrative lives. What is learned represents a take-away that exists in the context of a larger network of knowings - both personal/individual and shared/collective. What is known is the present understandings that have been previously communicated to self and within a particular context by a culture sharing group (discipline).

- What we call these "things" depends upon the context and language set shared by a particular group - poem, meaning, body, text, envisionment, event - each of these is taken up from a different scholar and the body of their work, a slightly different vantage point with heterogeneous theoretical and philosophical underpinnings, yet each is made whole, makes sense, is meaningful in the context of a classroom. Each speaks to a taking up, making sense, contributing, influencing, and a particular time and place; to mind, body, emotion, presence, biology, "thing ness," even that which we do not see and still sense (excitement, frustration); all of these happen in the context of the classroom. I speak about these aspects in terms of literacy, because it leans toward the multiple modes of communication we attend to in classroom life (and life beyond classrooms). Semiotics of teaching and learning. We have a 
responsibility to study our teaching practices, because in them are worlds of knowing, processes for making-meaning, insights into knowing. We include ourselves in this process because we have, through S-STEP methodology, a way to tap into the beliefs, fears, assumptions - the affective, cognitive, social, relational, historical, social; we are texts - works in progress, ever becoming. If we take responsibility to start where we are, to attend to what and how and why and with whom we know, how we make meaning, whose meaning is being made (and maybe isn't)...we develop a kind of critical consciousness and metacognition about the craft of teaching that gives us language and processes for helping our students - prospective and practicing teachers and educational researchers - the tools and models that can better equip them to develop and to benefit from the literacies of our education discipline. To "only" make meaning, to know, to learn - this is, or at least could be selfish. So what? And Why? And Who/What for? These yanking questions pull us back from the individual world in which we actively are reading the world and the word around us, composing and constructing meaning, contributing to the many cultures of which we are a part to consider, with real responsibility and agency, that which and who is beyond us. It is the "Ricky" who skips (or tries to skip) their other classes to be in Mrs. Ordaz's class, even though he has her for reading and for English class already. When I ask him to tell me why he wants to be here, he says he doesn't know exactly, but she says hello to him at the door, she asks him about his day, the posters on the wall--- he is recognizing a place, a context, where he is valued and where he is expected to continue becoming, where relationships exist, and he feels a part of something, an energy that is something and helps him to continue to become. "It" is why, in that same room, I write about a phenomenon I cannot explain (Edge, 2011; Edge, forthcoming), and yet, because my fingers are tap, tap taping on my keyboard, I happen to capture in words, like touching the hem of something great and beyond me; knowing it is more than enough in that moment to touch and be changed, although I cannot yet explain how and why.

There is more here, I'm certain of it, but/and for now, it is enough for me to begin to dig into the why, what, and how - to investigate the meanings I made and am making in the process of writing this interim text, afforded by the genre of the conference event, an artificial, yet respected "deadline" and context, a moment in time that compels me to stop reading and take a moment to write, and then to wrestle (painfully and also excitedly so) away from the moment in time long enough to, in a new moment, dig and investigate some of the potential meanings that I am living and writing. And, in that investigation, to consider (consciously or not) which meanings will next move forward, and to ask myself and ask of others, are these warranted and why? This prompts me to come back to the larger conference calls - that of our SIG and that of AERA, and to focus for a moment on the responsibility, the serious responsibility we have and share as educators who have a privileged position of knowing and knowledge from which we read the world around us, and through the languages and frameworks and Discourses in which we have access and through which we speak. We have privilege. Whether that makes us uncomfortable or not, whether we feel we have earned our place or not, we have access to resources, ways of knowing and being and becoming that compel us to take seriously the weighty and messy and beautiful work we do in our research and teaching.

I know that even this paper is packed with meanings that need to be unpacked and will be - this is to speak from a moment in a moment and to trust that in future moments, we can and will go beyond the bounds of the particular occasion. So, for today, what then? As we depart our shared moment and turn our attention to others, may we take up the following for consideration:

- Teaching and learning are meaning-making events

- The literacies, literacy practices, and tools for knowing are all around us, in us, through us and others

- We have a responsibility to attend to whose meanings are and are not being made, how our practices take up, or don't, those of others, why, and for what purposes

To not attend to our meaning-making processes as teacher educators and as educational researchers is to not acknowledge our privilege, position, and power; to not work toward equity, social justice, and democracy in the context of contributing to the becomings of the world and in the world all around us; to 
not consider the self in relation to other, and to not consider the teaching, learning, and researching in the context of a meaningful whole.

It is with this thought that I chose to metaphorically stand up, departing from this conversational circle, knowing that I have work to do. I may not yet know the details or the timeline, but, looking at this present occasion and context of the completed handbook chapter, I know it will be arduous, time intensive, weighty work that is both enjoyable and taxing and challenging. I will lean to literature as critical friends, and people as critical friends and collaborators. I will hope for opportunities and occasions such as this one which give rise to new thoughts and vantage points from which the tangled wonderings can be tugged at and learned from, both raveling and unraveling, stitching and unstitching, becoming and being, reading and writing, teaching and learning, researching and wondering, living and dying, through self, in and of self, for self, for others, with others, from others for purposes which touch the quick of humans being.

\section{REFERENCES}

Barr, R. (2001). Research on the teaching of reading. In V. Richardson (Ed.), Handbook of research on teaching (4th ed., pp. 390-415). American Educational Research Association.

Beers, K., \& Probst, R.E. (2012). Notice and note: Strategies for close reading. Heinemann.

Belenky, M.F., Bond, L.A., \& Weinstock, J.S. (1997). A tradition that has no name: Nurturing the development of people, families, and communities. Basic Books, Inc.

Belenky, M.F., Clinchy, B.M., Goldberger, N.R., \& Tarule, J.M. (1986). Women's ways of knowing: The development of self, voice, and mind. Basic Books, Inc.

Bergh, B., Edge, C., \& Cameron-Standerford, A. (2018). Reframing our use of visual literacy through academic diversity: A cross-disciplinary collaborative self-study. In J. Sharkey \& M.M. Peercy (Eds.), Self-study of language and literacy teacher education practices across culturally and linguistically diverse contexts (pp. 115-142). Emerald Group Publishing.

Bergh, B., Edge, C., Cameron-Standerford, A., Menard, K., VandenAvond, L., \& Johnson, K. (2020). Developing global understandings of online teaching practices: Transforming practices through collaborative self-study. In M. Brown, M. Goilla Mhichil, E. Bernie, \& E. Costello (Eds.), Proceedings of the 2019 ICDE World Conference on Online Learning, Volume 1 (pp. 69-77). ICDE.

Burnett, C., \& Merchant, G. (2021). Returning to text: Affect, meaning making, and literacies. Reading Research Quarterly, 56(2), 355-367.

Cameron-Standerford, A., Edge, C., \& Bergh, B. (2016). Toward a framework for reading lived experiences as texts: A four-year self-study of teacher education practices. In D. Garbett \& A. Ovens (Eds.), Enacting self-study as methodology for professional inquiry, (pp. 371-377). SSTEP.

Clandinin, D.J., \& Connelly, F.M. (2000). Narrative inquiry: Experience and story in qualitative research. Jossey-Bass.

Colflesh, N.A. (1996). Piece-making: The relationships between women's lives and the patterns and variations that emerge in their talk about school leadership (Unpublished doctoral dissertation). Michigan State University, East Lansing.

Connell, J.M. (2008). The emergence of pragmatic philosophy's influence on literary theory: Making meaning with texts from a transactional perspective. Educational Theory, 58(1), 102-122.

Crowe A.R. (2020) Self-Study Within and Across Disciplines. In J. Kitchen, A. Berry, S. Bullock, A. Crowe, H. Guðjónsdóttir, J. Kitchen, \& M. Taylor (Eds.), International handbook for self-study of teaching and teacher education (2nd ed., pp. 765-777). Springer. https://doi.org/10.1007/978981-13-6880-6_26

Dewey, J. (1938). Experience and education. Simon \& Schuster.

Dewey, J., \& Bentley, A.F. (1949). Knowing and the known. Beacon. 
Draper, R.J., \& Siebert, D. (2010). Rethinking texts, literacies, and literacy across the curriculum. In R.J. Draper, P. Broomhead, A. Petersen Jensen, J.D. Nokes, \& D. Siebert (Eds.), (Re)Imagining content-area literacy instruction (pp. 20-39). Teachers College Press.

Durkin, D. (1993). Teaching them to read (6th ed.). Allyn and Bacon.

Edge, C. (2011). Making meaning with 'readers' and 'texts': A narrative inquiry into two beginning English teachers' meaning-making from classroom events. Graduate School Theses and Dissertations. Retrieved from http://scholarcommons.usf.edu/etd/3722/

Edge, C. (2018). A teacher educator's meaning-making from a hybrid "Online Teaching Fellows" professional learning experience: Toward literacy practices for teaching and learning in multimodal contexts. In S. Keengwe (Ed.), Handbook of Research on Virtual Training and Mentoring of Online Instructors (pp. 76-109). IGI Global.

Edge, C. (2019). Lunch notes: Remember who we teach and why. Florida English Journal, 54(1), 51-53.

Edge, C., \& Olan, E.L. (2020). Reading, literacy, and English language arts teacher education: Making meaning from self-studies of teacher education practices. In J. Kitchen, A. Berry, S. Bullock, A. Crowe, H. Guðjónsdóttir, J. Kitchen, \& M. Taylor (Eds.). International handbook for self-study of teaching and teacher education (2nd ed., pp. 779-821). Springer. https://doi.org/10.1007/978981-13-6880-6_27

Edge, C., Cameron-Standerford, A., \& Bergh, B. (in press). In B. Butler \& S. Bullock (Eds.), Learning through collaboration in self-study: Communities of practice, critical friendship, and collaborative self-study. Springer.

Edge, C., Cameron-Standerford, A., Bergh, B. (2014). Using Self-Study to Navigate the Changing Seas of Standards-Based Education. In D. Garbett \& A. Ovens (Eds.), Changing Practices for Changing Times: Past, Present and Future Possibilities for Self-Study Research (pp. 63-66). Proceedings of the Tenth International Conference of Self-Study of Teacher Education Practices, Herstmonceux Castle, East Sussex, England. University of Auckland.

Edge, C.U. (forthcoming). Making meaning with readers and texts: Beginning teachers' meaning-making from classroom events. Advances in Research on Teaching Series. Emerald.

Edge, C.U., \& Olan, E.L. (2021). Learning to breathe again: Found poems and critical friendship as methodological tools in self-study of teaching practices. Studying Teacher Education. https://doi.org/10.1080/17425964.2021.1910807

Fecho, B. (2011). Teaching for the students: Habits of heart, mind, practice in the engaged classroom. Teachers College Press.

Gatlin, A., Peck, M., Aposhian, N., Hadley, S., \& Porter, A. (2002). Looking again at insider knowledge: A relational approach to knowledge production and assessment. Journal of Teacher Education, 53(4), 303-315.

Geertz, C. (1973). The interpretation of cultures. Basic Books.

Hall, L.A. (2006). IRA Outstanding Dissertation Award for 2006: Anything but lazy: New understandings about struggling readers, teaching, and text. Reading Research Quarterly, 41(4), 424-426.

Hamilton, M.L., Hutchinson, D.A., \& Pinnegar, S. (2020). Quality, trustworthiness, and S-STEP research. In J. Kitchen, A. Berry, S.M. Bullock, A.R. Crow, M. Taylor, H. Guðjónsdóttir, \& L. Thomas (Eds.), International handbook of self-study of teaching and teacher education (2nd ed., pp. 299338). Springer. https://doi.org/10.1007/978-981-13-6880-6_10

Harper, S.R., Davis, L.P., Jenkins, T.S., Soodjinda, D. (2021). Accepting Educational Responsibility. American Educational Research Association. Retrieved from https://www.aera.net/EventsMeetings/Annual-Meeting/2021-Annual-Meeting-Theme

Keen, E.O., \& Zimmerman, S. (2007). Mosaic of thought: The power of comprehension strategy instruction. Heinemann.

Kitchen, J. (2020). Envisioning writing as a way of knowing in self-study. In C. Edge, A. CameronStanderford \& B. Bergh (Eds.), Textiles and tapestries: Self-study for envisioning new ways of knowing. Equity Press. Retrieved from https://edtechbooks.org/textiles_tapestries_self_study/chapter_106 
LaBoksey, V.K. (2004). The methodology of self-study and its theoretical underpinnings. In J.J. Loughran, M.L. Hamilton, V.K. LaBoskey, \& T. Russell (Eds.), International handbook of selfstudy of teaching practices (pp. 817-869). Kluwer Academic Publishers.

Langer, J.A. (2011). Envisioning knowledge: Building literacy in the academic disciplines. New York, NY: Teachers College Press.

Levine, S. (2014). Making interpretation visible with an affect-based strategy. Reading Research Quarterly, 49(3), 283-303.

Martin, A., \& Mills, T. (2020). AERA 2021 self-study of teacher education practices SIG call for proposals.

Miles, M., \& Huberman, A. (1994). Qualitative data analysis. Sage.

Moje, E.B., Dillon, D.R., \& O’Brien. D. (2000). Reexamining roles of learner, text, and context in secondary literacy. Journal of Educational Research, 93(3), 165-180.

Olan, E.L., \& Edge, C. (2019). Collaborative meaning-making and dialogic interactions in critical friends as co-authors. Studying Teacher Education, 15(1), 31-43. doi: 10.1080/17425964.2019.1580011

Parsons, L.T. (2015). Learning from preservice teachers' responses to trans-themed young adult literature: Improving personal practice in teacher education. Discourse: Studies in the Cultural Politics of Education, 37(6), 933-947.

Pinnegar, S., \& Hamilton, M.L. (2009). Self-study of practice as a genre of qualitative research: Theory, methodology, and practice. Springer.

Pinnegar, S., Hutchinson, D.A., \& Hamilton, M.L. (2020). Role of positioning, identity and stance in becoming S-STEP researchers. In J. Kitchen, A. Berry, S.M. Bullock, A.R. Crow, M. Taylor, H. Guðjónsdóttir, \& L. Thomas (Eds.), International handbook of self-study of teaching and teacher education (2nd ed., pp. 97-133). Springer. https://doi.org/10.1007/978-981-13-6880-6_4

Polkinghorne, D.E. (1988). Narrative knowing and the human sciences. State University of New York Press.

Purcell-Gates, V., Duke, N., \& Stouffer, J. (2017). Teaching literacy: Reading. In D.H. Gitomer \& C.A. Bell (Eds.), Handbook of research on teaching (5th ed., pp. 1217-1267). American Educational Research Association.

Richardson, L. (2000). Writing: A method of inquiry. In N.K. Denzin \& Y.S. Lincoln (Eds.), Handbook of qualitative research (2nd ed., pp. 923-948). Sage.

Richardson, L., \& St. Pierre, E.A. (2005). Writing: A method of inquiry. In N.K. Lincoln \& Y.S. Lincoln (Eds.), The sage handbook of qualitative research (3rd ed., pp. 959-978). Sage.

Rosenblatt, L. (1938). Literature as exploration. Modern Language Association.

Rosenblatt, L. (1969). Toward a transactional theory of reading. Journal of Reading Behavior, 1(1), $31-$ 47.

Rosenblatt, L. (1978/1994). The reader, the text, the poem: The transactional theory of the literary work. Southern Illinois University Press.

Rosenblatt, L. (1985). The transactional theory of the literary work: Implications for research. In C. Cooper (Ed.), Researching response to literature and the teaching of literature (pp. 33-35). Ablex.

Rosenblatt, L. (1994). The transactional theory of reading and writing. In R.R. Ruddell, M.R. Ruddell, \& H. Singer (Eds.), Theoretical Models and Processes of Reading (4th ed., pp. 1057-1092). International Reading Association.

Rosenblatt, L. (2005). Making meaning with texts: Selected essays. Heinemann.

Russell, T. (2004). Tracing the development of self-study in teacher education research and practice. In J.J. Loughran, M.L. Hamilton, V.K. LaBoskey, \& T. Russell (Eds.), International handbook of self-study teaching and teacher education practices (pp. 1191-1210). Springer.

Strauss, A., \& Corbin, J. (1998). Basics of qualitative research: Techniques and procedures for developing grounded theory. Sage.

Thomas, M. (2018). "The girl who lived": Exploring the liminal spaces of self-study research with textual critical partners. In D. Garbett \& A. Ovens (Eds.), Pushing boundaries and crossing borders: 
Self-study as a means for researching pedagogy (pp. 327-333). S-STEP. ISBN: 978-0-47344471-6

Tovani, C. (2004). Do I really have to teach reading? Content comprehension, grades 6-12. Stenhouse. Unrau, N.J., Alvermann, D.E., \& Ruddell, R.B. (2013). "Section Three: Models of Reading and Writing Processes.” In N.J. Unrau, D.E. Alvermann, \& R.B. Ruddell (Eds.), Theoretical Models and Processes of Reading (6th ed., pp. 691-697). International Reading Association.

Vanassche, E., \& Kelchtermans, G. (2015). The state of the art in self-study of teacher education practices: A systematic literature review. Journal of Curriculum Studies, 47(4), 508-528. 